\title{
DEVELOPMENT OF POLYHERBAL WITH ANTIOXIDANT ACTIVITY
}

\author{
JAIN DEEPAK ${ }^{1,2 *}$, JAIN ANUREKHA ${ }^{3}$ \\ ${ }^{1}$ Centre for Research and Development, Pacific Academy of Higher Education and Research University, Udaipur - 313 024, Rajasthan, India. \\ ${ }^{2}$ Department of Pharmacognosy, B. R. Nahata College of Pharmacy, MU University, Mandsaur - 458 001, Madhya Pradesh, India. ${ }^{3}$ Dean, \\ Jayoti Vidyapeeth Women’s University, Jaipur - 303 122, Rajasthan, India. Email: deep_nisha99@rediffmail.com
}

Received: 07 March 2018, Revised and Accepted: 19 June 2018

ABSTRACT

Objective: The objective of this research was to develop a polyherbal formulation (PHF) using four different herbs and to evaluate their phytochemicals, physical constants, and determination of their antioxidant activity by DPPH method.

Methods: The PHF authenticated herbs were characterized by studying its morphological and pharmacognostic characters. Phytochemical screening showed the presence of alkaloids, glycosides, carbohydrates, amino acid, tannin, steroids, and flavonoids in the combination extract. Physical parameters such as loss on drying (LOD), $\mathrm{pH}$, ash values, LOD, and extractive value have been studied. The antioxidant activity of the combination of extract (100 mg each) was determined using DPPH free radical scavenging method.

Results: The results showed that the combination extract has best antioxidant effect at a dose of $400 \mu \mathrm{g} / \mathrm{ml}$ when it was compared with ascorbic acid as the reference standard.

Conclusion: The results obtained in this research work clearly showed that the combination extract has best antioxidant effect at a dose of $400 \mu \mathrm{g} / \mathrm{ml}$ when it was compared with ascorbic acid as the reference standard.

Keywords: Polyherbal formulation (PHF), Phytochemical, Antioxidant activity, Ascorbic acid.

(c) 2018 The Authors. Published by Innovare Academic Sciences Pvt Ltd. This is an open access article under the CC BY license (http://creativecommons. org/licenses/by/4. 0/) DOI: http://dx.doi.org/10.22159/ajpcr.2018.v11i8.27791

\section{INTRODUCTION}

In the past few years, there has been significant growth in the arena of herbal treatment. It is getting propagated in the emergent countries due to its natural origin and lesser side effects [1]. It is categorized in the olden Indian system of medicine.

An antioxidant is defined as a molecule capable of inhibiting the oxidation of other molecules. Oxidation is a chemical reaction that transfers electrons from a substance to an oxidizing agent. Oxidation reactions can produce free radicals. In turn, these radicals can start chain reactions that damage cells. Antioxidant terminates these chain reactions by removing free radical and inhibits other oxidation reactions. They do so by being oxidized themselves; so antioxidants act often as reducing agents such as thiols, ascorbic acid, or polyphenols. Many studies had revealed that phenolic content in plants could be correlated to their antioxidant activities. Plants contained phenolic, and polyphenol compounds can act as an antioxidant [2]. Oxidative-process is the most common route for producing free radicals in food, drugs, and even in living systems [3]. The majority of free radicals that damage biological systems are oxygen radicals.

Antioxidants also act as radical scavengers, hydrogen donors, electron donors, peroxide decomposers, singlet oxygen quenchers, enzyme inhibitors, and metal chelating agents [4]. Due to the effect on immune system, there is a need for natural antioxidants (safe and nontoxic) as compared to synthetic antioxidants (toxic for human).

Plants contain many constituents with local physical impact on body tissues, and the topical use of herbal remedies is among the most noticeable in the simplest traditions of health care [5]. To support the usage of selected plant extracts in Ayurveda, the antioxidant potential of the fruits of Momordica charantia Linn., bark of Eugenia jambolana Linn., fruits of Ziziphus mauritiana Lam., and bark of Acacia catechu Willd. of Indian origin was examined. The objective of this work was to assess the antioxidant activity of the combination of extract (polyherbal formulation [PHF]) by in vitro studies and relate them with ascorbic acid, a known antioxidant.

\section{METHODS}

\section{Plant material and authentication}

Identification of plant was done by Dr. C.K. Nigwal (Department of Botany), P.G. College of Mandsaur (M.P.). Fruits of M. charantia Linn., dried bark of E. jambolana Linn., dried fruits of Z. mauritiana Lam., and dried bark of $A$. catech $u$ Willd. were collected from the Mandsaur region. The taxonomical identification of plant was done by Dr. C.K. Nigwal (Department of Botany), P.G. College of Mandsaur (M.P.). The voucher specimen M. charantia Linn. (BRNCP/M/004/2007), E. jambolana Linn. (BRNCP/E/003/2012), Z. mauritiana Lam. (BRNCP/Z/001/2006), and A. catechu Willd. (BRNCP/A/008/2006) were deposited in the herbarium of the Department of Pharmacognosy, B.R. Nahata College of Pharmacy, Mandsaur.

\section{Preparation of extracts}

$50 \mathrm{~g}$ of M. charantia Linn., E. jambolana Linn., Z. mauritiana Lam., and A. catechu Willd. dried plant material were exhaustively extracted with chloroform, ethyl acetate, ethanol, and water using Soxhlet extraction apparatus. The extracts were evaporated above their boiling points. Finally, the percentage yields were calculated of the dried extracts.

\section{Phytochemical screenings}

To determine the presence of alkaloids, glycosides, flavonoids, tannins, steroids, saponins, and carbohydrates, a preliminary phytochemical study with various plants extracts was performed [6-9].

\section{Physical evaluation of extract}

The physical evaluation of the combination of all extract was done for following parameters. The results are shown in Table 1. 
1. Moisture content (Loss on drying at $105^{\circ} \mathrm{C}$ ).

2. Ash value.

3. Extractive value.

4. $\mathrm{pH}$.

5. Swelling Index

Determination of antioxidant activity by DPPH method

The capability of the formulation to scavenge the DPPH radical was calculated using the formula, Percentage inhibition $=($ AC-AS $) / A C \times 100$

Where, AC is absorbance of control; AS is the absorbance of sample.

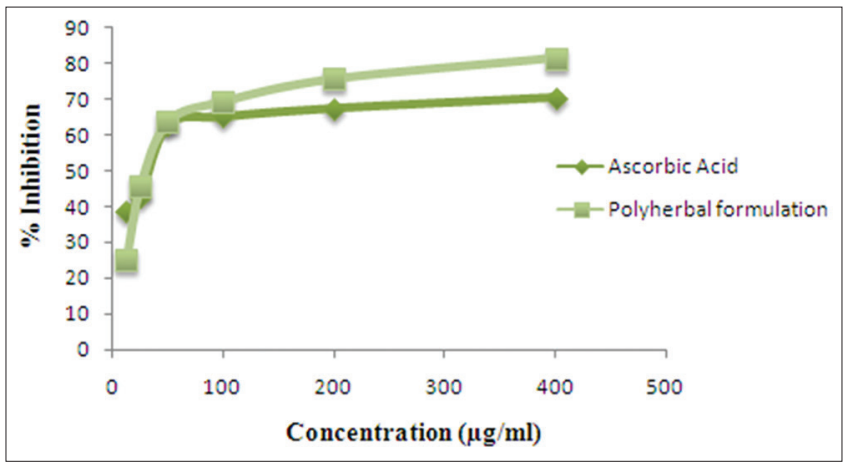

Fig. 1: Antioxidant activity of polyherbal extract

\section{RESULTS AND DISCUSSION}

In vitro antioxidant assay of the polyherbal compound (combination) revealed the presence of antioxidant potential. The percentage of inhibition was observed that free radicals were scavenged by the test compounds in a concentrated manner in the methods. Table 2 depicts, the results of phytochemical analysis were observed that the presence of flavonoids, phenols, tannins, alkaloids, steroids, and carbohydrates and Table 2 shows the physical evaluation of individual and combination extract.

The DPPH scavenging activities were recorded in terms of percentage inhibition observed from Table 3 that the combination has maximum DPPH. The results obtained were compared to standard ascorbic acid. Higher the percentage inhibition indicates better scavenging activity or antioxidant potential. The results obtained were statistically significant with $\mathrm{p}<0.05$

\section{CONCLUSION}

The result obtained from above study indicates the presence of flavonoids, steroids, glycosides, and tannins in the PHF. The antioxidant screening done using DPPH method showed a good antioxidant potential as compared to reference standard drug. From the above study, we can conclude that PHF possesses promising antioxidant activity which can be considered as a base for further pharmacological evaluation.

Table 1: Physical evaluation of individual and combination of extract

\begin{tabular}{|c|c|c|c|c|c|}
\hline \multirow[t]{2}{*}{ S. No. } & \multirow[t]{2}{*}{ Parameters } & \multicolumn{4}{|l|}{ Result } \\
\hline & & M. Charantiana Linn. & E. Jambolana & Z. Maurantiana & A. catechu \\
\hline 1. & Moisture content (Loss on drying at $105^{\circ} \mathrm{C}$ ) & $7.47 \pm 0.060$ & $4.47 \pm 0.047$ & $7.61 \pm 0.061$ & $10.19 \pm 0.458$ \\
\hline 3. & Acid insoluble ash & $0.73 \pm 0.120$ & $1.33 \pm 0.124$ & $3.66 \pm 0.132$ & $0.44 \pm 0.036$ \\
\hline 4. & Water-soluble ash & $6.46 \pm 0.124$ & $3.39 \pm 0.147$ & $4.31 \pm 0.177$ & $0.29 \pm 0.041$ \\
\hline 5. & Water-soluble extractives & $25.08 \pm 0.716$ & $23.12 \pm 0.656$ & $12.97+0.448$ & $23.74 \pm 0.451$ \\
\hline 6. & Alcohol soluble extractives & $8.21 \pm 0.103$ & $13.98 \pm 0.677$ & $15.57 \pm 0.324$ & $19.74 \pm 0.506$ \\
\hline 7. & $\mathrm{pH}$ of water extract & $5.42 \pm 0.163$ & $5.71 \pm 0.217$ & $5.26 \pm 0.008$ & $6.05 \pm 0.037$ \\
\hline 8. & Swelling index & 4.18 & 4.28 & 3.7 & 5.00 \\
\hline
\end{tabular}

M. Charantia: Momordica Charantia, E. Jambolana: Eugenia Jambolana, Z. Mauritiana: Ziziphus Mauritiana, A. catechu: Acacia catechu

Table 2: Phytochemical results of individual and combination of extract

\begin{tabular}{llllll}
\hline S. No. & Chemical Test & $\begin{array}{l}\text { Momordica } \\
\text { charantia }\end{array}$ & $\begin{array}{l}\text { Eugenia } \\
\text { Jambolana }\end{array}$ & $\begin{array}{l}\text { Ziziphus } \\
\text { mauritiana }\end{array}$ & $\begin{array}{l}\text { Acacia } \\
\text { catechu }\end{array}$ \\
\hline 1. & Alkaloid & + & + & + & + \\
of all extract
\end{tabular}

M. charantia: Momordica charantia, E. Jambolana: Eugenia Jambolana, Z. mauritiana: Ziziphus mauritiana, A. catechu: Acacia catechu

Table 3: DPPH activity of polyherbal formulation with reference to ascorbic acid

\begin{tabular}{llll}
\hline S. No. & Concentration $(\mu \mathbf{g m} / \mathbf{m l})$ & Ascorbic acid $(\%$ inhibition) & Polyherbal formulation (\% inhibition) \\
\hline 1 & 12.5 & 38.66 & 25.11 \\
2 & 25 & 42.87 & 45.68 \\
3 & 50 & 62.97 & 63.79 \\
4 & 100 & 65.19 & 69.39 \\
5 & 200 & 67.52 & 75.70 \\
6 & 400 & 70.56 & 81.54 \\
IC 50 value & & 11.66 & 37.50 \\
\hline
\end{tabular}




\section{ACKNOWLEDGMENTS}

I am very much thankful to Dr. Anurekha Jain Dean, Jayoti Vidyapeeth Women's University, Jaipur, Rajasthan, for supporting me for the completion of this research work.

\section{AUTHOR'S CONTRIBUTION}

All the authors have equally contributed.

\section{CONFLICTS OF INTERESTS}

All authors have none to declare.

\section{REFERENCES}

1. Khopde SM, Darshini P, Mohan H, Gawandi VB. Characterizing the antioxidant activity of amla (Phyllanthus emblica) extract. Curro Sci 2001;81:185-190.

2. Irda F, Evelyne N, Komar RW. In vitro antioxidant activities, total flavonoid, phenolic and carotenoid content from various extracts of four species asteraceae herb. Int J Pharm Pharm Sci (IJPPS) 2015;7:192-7.

3. Well H, Gutteridge JM. Free Radicals in Biology and Medicine OS'ed. Oxford: Clarendon Press; 1985

4. Gutteridge JM, Halliwell B. Free radicals and antioxidants in the year 2000. A historical look to the future. Ann N Y Acad Sci 2000;899:136- 47.

5. Zerargui F, Baghiani A, Khennouf S, Arrar L. Antioxidant activity assessment of Tamus communis L. Roots. Int J Pharm Pharm Sci (IJPPS) 2016;8:64-71

6. Jarald EE, Joshi SB, Jain DC. Biochemical study on the hypoglycemic effect of extracts and fractions of Acacia catechu Willd. in alloxan induced diabetic rats. Int J Diabetes Metab 2009;17:62-9.

7. Kokate CK, Purohit AP, Gokhale SB. Pharmacognosy. $3^{\text {rd }}$ ed. Pune: Nirali Prakashan; 1995. p. 218-9.

8. Khandewal KR. Practical Pharmacognosy. $19^{\text {th }}$ ed. Pune: Nirali Prakashan; 2008. p. 24-7.

9. Alam MN, Bristi NJ. Review on in vivo and in vitro methods evaluation of antioxidant activity. Saudi Pharm J 2013;21:143-52. 